\title{
EVALUATION OF OXIDATIVE STRESS, ANTIOXIDANT AND THYROID HORMONE STATUS IN PATIENTS WITH DIABETES MELLITUS
}

\author{
P PASUPATHI ${ }^{1}, \mathrm{VCHANDRASEKAR}^{2}$, USENTHIL KUMAR ${ }^{2}$
}

\begin{abstract}
Oxidative stress is currently suggested as mechanism underlying diabetes and diabetic complications. The aim of the study was to evaluate the magnitude of oxidative stress in patients with diabetes by measuring the lipid peroxidation as well as the status of the antioxidant defense system, thyroid hormones status and other biochemical variables. The study population consisted of 100 subjects divided into two groups viz. diabetic $(n=50)$ and healthy controls $(n=50)$. Changes in the levels of lipid peroxidation and antioxidants and thyroid hormones status were determined in diabetic and non-diabetic subjects. The level of thiobarbituric acid reactive substances (TBARS) was found to be increased significantly in diabetic patients compared to healthy controls. On the other hand, the activities of superoxide dismutase (SOD), catalase (CAT), glutathione peroxidase (GPX), glutathione-S-transferase (GST), reduced glutathione (GSH), vitamin A, vitamin E and vitamin $C$ were found to be decreased significantly in diabetics when compared to control subjects. We also noticed a marked increase in serum total cholesterol, triglyceride, low-density lipoprotein cholesterol (LDL-C), very low-density lipoprotein cholesterol $(V L D L-C)$, and decrease in highdensity lipoprotein cholesterol (HDL-C), total protein and albumin in diabetic patients. The level of TSH was significantly decreased whereas the levels of T4 and FT4 were significantly increased in diabetic patients than the control subjects. However, the T3 and FT3 levels did not differ significantly between groups. Our findings indicate that changes in oxidant and antioxidant equilibrium will have biological and possibly pathological role in the development of secondary complications. It also demonstrate that detection of thyroid hormone status in the early stage of the disease will help the patients to improve quality of life and reduce the morbidity rate.
\end{abstract}

Key Words: Diabetes mellitus, Oxidative stress, Lipid peroxidation, Antioxidant status, Thyroid hormones.

\section{Introduction}

Diabetes mellitus is the most common endocrine metabolic disorder, affecting about 170 million people worldwide. ${ }^{1}$ Defects in glucose metabolizing machinery and consistent efforts of the physiological system to correct the imbalance in glucose metabolism place an over exertion on the endocrine system. Continuing deterioration of endocrine control exacerbates the metabolic disturbances and leads primarily to hyperglycemia ${ }^{2}$. Prolonged exposure to elevated glucose induces both repeated acute changes in intracellular metabolism and cumulative long-term changes in the structure and function of macromolecules. ${ }^{3}$ The injurious effects of hyperglycemia are characteristically observed in tissues that are not dependent on insulin for glucose entry into the cell. ${ }^{4}$

Free radicals are very reactive chemical species, can cause oxidative injury to the living beings by attacking the macromolecules like lipids, carbohydrates, proteins and nucleic acids. Under normal physiological conditions, there is a critical balance in the generation of oxygen free radicals and antioxidant defense systems used by organisms to deactivate and protect themselves against free radical toxicity ${ }^{5}$. Impairment in the oxidant/antioxidant equilibrium creates a condition known as oxidative stress. Oxidative stress

1. Institute of Laboratory Medicine, K.G. Hospital and Postgraduate Medical Institute, Coimbatore-641 018, Tamil Nadu, India

2. Institute of Laboratory Medicine; Department of Microbiology, Bio Line Research Institute, Coimbatore- 641018 , Tamil Nadu, India

Correspondence : Dr. P. Pasupathi, Head -Department of Clinical Biochemistry, Institute of Laboratory Medicine, K.G. Hospital and Post Graduate Medical Institute, Coimbatore-641 018, Tamil Nadu, India. E-mail: drppasupathi@gmail.com 
is known to be a component of molecular and cellular tissue damage mechanisms in a wide spectrum of human diseases. ${ }^{6,7}$

Formation of lipid peroxides by the action of free radicals on unsaturated fatty acids has been implicated in the pathogenesis of atherosclerosis and vascular diseases ${ }^{8}$ Increased levels of the products of oxidative damage to lipids have been detected in serum of diabetic patients, and their presence correlates with the development of complications. ${ }^{9,10}$

The influence of other endocrine and non-endocrine organs other than the pancreas on diabetes mellitus is documented. Occasionally other endocrine disorders such as abnormal thyroid hormones levels are found in diabetes ${ }^{11}$. In chemically induced diabetic animals, the alterations in the hypothalamo-pituitary-thyroid axis in diabetic rats are numerous; hypothalamic and plasma TRH, pituitary and plasma TSH, as well as TSH secretion rate are reduced, and the TSH response to TRH is decreased despite normal peripheral TSH metabolism. $\mathrm{T}_{3}$ and $\mathrm{T}_{4}$ production and iodide uptake by the thyroid are diminished. There are also important structural changes in the thyroid gland and pituitary that are accompanied by marked alterations in their secretory activity. In addition, $\mathrm{T}_{4}$ deiodination to $\mathrm{T}_{3}$ in peripheral tissues is decreased 12,13 . It is found that iodothyronines are insulin antagonist with high levels being diabetogenic while absence of the hormone inhibits the development of diabetes. ${ }^{14}$ Hence the present study was undertaken to assess the extent of lipid peroxidation and the status of the antioxidant defense system and thyroid hormone abnormalities in patients with diabetes.

\section{Materials and Methods}

\section{Study population}

The study population consisted of 100 subjects (agematched male subjects) divided in to two groups viz., diabetic patients (type 2 diabetic subjects; $n=50$ ) and healthy controls $(n=50)$. The prospective study was carried out at Bio Line Research Institute, Coimbatore, Tamil Nadu, India, during June 2006 to December 2007. General health characteristics such as age, sex, smoking status, menopausal status, alcohol consumption, and dietary habits, particularly as related to preference were investigated by a selfadministered questionnaire.

Each diabetic and non-diabetic subject was physically examined to rule out thyroid disorders. In addition, none of the subjects had a history of previous thyroid disease. Age and sex-matched healthy volunteers without history of diabetes were considered as control subjects. All subjects were informed about the objectives of the study and what roles they were expected to play. The study excluded very ill patients with complications of diabetes mellitus and those with known history of thyroid dysfunction. All samples were specimens taken from subjects who fasted for at least $8 \mathrm{hr}$ before the blood collection.

Classification of the values into raised, low or normal thyroid hormone levels were based on the following criteria. Subjects classified as having raised level of thyroid hormones: had $\mathrm{FT}_{4}$ values $>1.6 \mathrm{ng} / \mathrm{l}$ or, $\mathrm{TSH}$ $<0.4 \mathrm{miu} /$ or both, those classified as having Low level had $\mathrm{FT}_{4}$ values $<0.68 \mathrm{ng} / \mathrm{ml}$, or TSH values $>5.0 \mathrm{miu} /$ $\mathrm{ml}$, or both. Subjects grouped as normal had $\mathrm{FT}_{4}$ and TSH values within the range $>0.68-1.6 \mathrm{ng} / \mathrm{ml}$, and $0.4-5.0 \mathrm{miu} / \mathrm{ml}$ respectively.

\section{Sample collection and hemolysate preparation}

Blood samples were collected by venous puncture in heparinized tubes and the plasma was separated by centrifugation at $1000 \mathrm{~g}$ for $15 \mathrm{~min}$. After the collection of plasma, the buffy coat was removed and the packed cells were washed thrice with cold physiological saline. A known volume of the erythrocytes was lysed with hypotonic phosphate buffer ( $\mathrm{pH}$ 7.4). The hemolysate was separated by centrifugation at $2,500 \mathrm{~g}$ for $10 \mathrm{~min}$ at $2^{\circ} \mathrm{C}$. Biochemical estimations were carried out immediately.

\section{Determination of blood glucose, HbA1C, serum lipids and proteins}

Biochemical investigation including blood glucose, $\mathrm{HbA} 1 \mathrm{C}$, urea, creatnine, total protein, albumin, total cholesterol, triglyceride, HDL-C and LDL-C were determined using fully automated clinical chemistry analyzer (Hitachi 912, Boehringer Mannheim, Germany). Serum VLDL-C was calculated according to Friedewald et al ${ }^{15}$.

The levels of serum thyroid stimulating hormone (TSH), total triiodothyroxine $\left(\mathrm{T}_{3}\right)$, free thyroxine $\left(\mathrm{FT}_{4}\right)$ and free triiodothyronine $\left(\mathrm{FT}_{3}\right)$ were measured by a Microparticle Enzyme Immunoassay (MEIA) on AXSYM System (Abbott Laboratories, Abbott Park, USA) while serum total thyroxine $\left(\mathrm{T}_{4}\right)$ was measured by the Fluorescence Polarization Immunoassay (FPIA) method on AXSYM System using the standard laboratory methodologies. 


\section{Estimation of lipid peroxidation}

Lipid peroxides were estimated by measurement of thiobarbituric acid reactive substances in plasma by the method of Yagi ${ }^{16}$. The pink chromogen produced by the reaction of thiobarbituric acid with malondialdehyde, a secondary product of lipid peroxidation was estimated. The absorbance of clear supernatant was measured against reference blank at $535 \mathrm{~nm}$.

Assay of superoxide dismutase (SOD) and catalase (CAT)

SOD was assayed utilizing the technique of Kakkar et al. ${ }^{17}$ based on inhibition of the formation of nicotine amide adenine dinucleotide, phenazine methosulfate and amino blue tetrazolium formazan. A single unit of enzyme was expressed as 50\% inhibition of NBT (nitroblue tetrazolium) reduction/min/mg protein.

CAT was assayed colorimetrically at $620 \mathrm{~nm}$ and expressed as $\mu$ moles of $\mathrm{H}_{2} \mathrm{O}_{2}$ consumed $/ \mathrm{min} / \mathrm{mg}$ protein as described by Sinha ${ }^{18}$. The reaction mixture (1.5 ml, vol) contained $1.0 \mathrm{ml}$ of $0.01 \mathrm{M}$ phosphate buffer (pH 7.0), $0.1 \mathrm{ml}$ of erythrocyte lysate and 0.4 $\mathrm{ml}$ of $2 \mathrm{M} \mathrm{H}_{2} \mathrm{O}_{2}$. The reaction was stopped by the addition of $2.0 \mathrm{ml}$ of dichromate-acetic acid reagent ( $5 \%$ potassium dichromate and glacial acetic acid were mixed in 1:3).

Assay of glutathione peroxidase (GPx) and reduced glutathione (GSH)

GPx activity was measured by the method described by Rotruck et al ${ }^{19}$. Briefly, reaction mixture contained $0.2 \mathrm{ml}$ of $0.4 \mathrm{M}$ Tris-HCl buffer $\mathrm{pH} 7.0,0.1 \mathrm{ml}$ of 10 $\mathrm{mM}$ sodium azide, $0.2 \mathrm{ml}$ of homogenate (homogenized in $0.4 \mathrm{M}$, Tris- $\mathrm{HCl}$ buffer, $\mathrm{pH}$ 7.0), $0.2 \mathrm{ml}$ glutathione, $0.1 \mathrm{ml}$ of $0.2 \mathrm{mM} \mathrm{H}_{2} \mathrm{O}_{2}$. The contents were incubated at $37^{\circ} \mathrm{C}$ for $10 \mathrm{~min}$. The reaction was arrested by 0.4 $\mathrm{ml}$ of $10 \%$ TCA, and centrifuged. Supernatant was assayed for glutathione content by using Ellmans reagent (19.8 $\mathrm{mg}$ of 5, 5'-dithiobisnitro benzoic acid (DTNB) in $100 \mathrm{ml}$ of $0.1 \%$ sodium nitrate). GSH was determined by the method of Ellman ${ }^{20} .1 .0 \mathrm{ml}$ of supernatant was treated with $0.5 \mathrm{ml}$ of Ellmans reagent and $3.0 \mathrm{ml}$ of phosphate buffer $(0.2 \mathrm{M}, \mathrm{pH}$ 8.0). The absorbance was read at $412 \mathrm{~nm}$.

\section{Assay of glutathione-S-transferase (GST)}

The GST activity was determined spectrophotometrically by the method of Habig, Pabst and Jakoby $^{21}$. The reaction mixture contained $1.0 \mathrm{ml}$ of $0.3 \mathrm{mM}$ phosphate buffer (pH 6.5), $0.1 \mathrm{ml}$ of $30 \mathrm{mM} 1$ chloro-2, 4-dinitrobenzene (CDNB) and $1.7 \mathrm{ml}$ of double distilled water. After preincubating the reaction mixture at $37^{\circ} \mathrm{C}$ for $5 \mathrm{~min}$, the reaction was started by the addition of $0.1 \mathrm{ml}$ of homogenate and $0.1 \mathrm{ml}$ of glutathione as substrate. The absorbance was followed for $5 \mathrm{~min}$ at $340 \mathrm{~nm}$. Reaction mixture without the enzyme was used as blank. The activity of GST is expressed as iM of GSH-CDNB conjugate formed $/ \mathrm{min} /$ mg protein using an extinction coefficient of $9.6 \mathrm{mM}^{-}$ ${ }^{1} \mathrm{~cm}^{-1}$. Protein was determined by the method of Lowry, Rosenbrough, Farr and Randall ${ }^{22}$ using Bovine Serum Albumin (BSA) as standard, at $660 \mathrm{~nm}$.

\section{Estimation of non-enzymatic antioxidants}

Plasma vitamin A ( $\beta$-carotene) was estimated by the method of Bradle and Hombeck ${ }^{23}$. Proteins were precipitated with ethanol and the carotenes were extracted into light petroleum. The intensity of the yellow color due to carotene was read directly at 450 $\mathrm{nm}$ using a violet filter. Vitamin $\mathrm{E}$ was measured by the method of Baker et al ${ }^{24}$ on the basis of the reduction of ferric ions to ferrous ions by vitamin $\mathrm{E}$ ( $\alpha$-tocopherol) and the formation of a red colored complex with 2.2'-dipyridyl at $520 \mathrm{~nm}$. Vitamin C (ascorbic acid) was estimated by the method of Roe and Kuether ${ }^{25}$. This involves oxidation of ascorbic acid by copper followed by treatment with 2, 4dinitrophenylhydrazine that undergoes rearrangement to form a product with absorption maximum at $520 \mathrm{~nm}$.

\section{Statistical analysis}

All data were expressed as mean $\pm \mathrm{SD}$. The statistical significance was evaluated by Student's t test using Statistical Package for the Social Sciences (SPSS Cary, NC, USA) version 10.0.

\section{Results}

Table-I shows the information about the investigated characteristics of study population. The mean age limit was $40 \pm 15$ years in diabetic patients and $42 \pm 12$ years in control subjects.

\section{Table-I}

Demographic characteristics of control and diabetic patients

\begin{tabular}{lcc}
\hline Parameter & $\begin{array}{c}\text { Control } \\
\text { subjects }\end{array}$ & $\begin{array}{c}\text { Diabetic } \\
\text { patients }\end{array}$ \\
\hline Age (year) & $42 \pm 12$ & $40 \pm 15^{\mathrm{NS}}$ \\
Smokers (\%) & $10 \%$ & $25 \%$ \\
Alcohols (\%) & $15 \%$ & $28 \%$ \\
Hypertension (\%) & $2 \%$ & $18 \%$ \\
Diabetes mellitus (\%) & - & $100 \%$ \\
Body mass index $\left(\mathrm{kg} / \mathrm{m}^{2}\right)$ & $30 \pm 6.2$ & $35 \pm 6.2^{* * *}$ \\
\hline
\end{tabular}

Values are given as mean \pm S.D from 50 subjects in each group. Diabetic patients compared with control subjects. $(* * * \mathrm{p}<0.001$, NS-Not significant) 
A significant increase in body mass index (BMI) was observed in diabetic patients $\left(35 \pm 6.2 \mathrm{~kg} / \mathrm{m}^{2}\right)$ when compared to control subjects $\left(30 \pm 6.2 \mathrm{~kg} / \mathrm{m}^{2}\right)$. Diabetic participants were defined as those with a fasting blood glucose concentration minimum $\geq 120 \mathrm{mg} / \mathrm{dl}$.

Table-II shows the levels of blood glucose, $\mathrm{HbA}_{1 \mathrm{C}}$, microalbuminurea, urea, creatnine, serum lipids and proteins in control and diabetic subjects.

\section{Table-II}

Comparison of biochemical changes in control and diabetic subjects

\begin{tabular}{lcc}
\hline Parameter & $\begin{array}{c}\text { Control } \\
\text { subjects }\end{array}$ & $\begin{array}{c}\text { Diabetic } \\
\text { patients }\end{array}$ \\
\hline Blood glucose (mg/dl) & & \\
Fasting & $92 \pm 13$ & $215 \pm 37^{* * *}$ \\
Postprandial & $125 \pm 25$ & $373 \pm 30^{* * *}$ \\
HbA $_{1 \mathrm{C}}(\%)$ & $3.2 \pm 1.7$ & $13.3 \pm 2.01^{* * *}$ \\
Microalbuminurea (mg/l) & $9 \pm 7$ & $35 \pm 20^{* * *}$ \\
Urea (mg/dl) & $21 \pm 15$ & $30 \pm 20^{* *}$ \\
Creatnine (mg/dl) & $0.5 \pm 0.3$ & $1.1 \pm 0.9^{* *}$ \\
Total protein (g/dl) & $7.5 \pm 0.6$ & $5.9 \pm 1.0 * * *$ \\
Albumin (g/dl) & $4.2 \pm 1.2$ & $3.3 \pm 0.6 * * *$ \\
Total cholesterol & $160 \pm 15$ & $190 \pm 22^{* *}$ \\
Triglyceride (mg/dl) & $120 \pm 30$ & $165 \pm 40^{* *}$ \\
HDL-C (mg/dl) & $45 \pm 7$ & $37 \pm 12^{*}$ \\
LDL-C (mg/dl & $60 \pm 13$ & $85 \pm 15^{* *}$ \\
VLDL-C (mg/dl) & $32 \pm 10$ & $42 \pm 17^{*}$ \\
\hline
\end{tabular}

Values are given as mean \pm S.D from 50 subjects in each group.

Diabetic patients compared with control subjects. $\left({ }^{*} \mathrm{p}<0.05,{ }^{* *} \mathrm{p}<0.01,{ }^{* * *} \mathrm{p}<0.001\right)$

The level of blood glucose, $\mathrm{HbA1}_{\mathrm{C}}$, microalbuminurea, urea, creatnine and serum lipids was significantly increased in diabetics than non-diabetic subjects. On the other hand, the levels of serum total protein; albumin and HDL-C were significantly decreased in diabetic patients when compared to healthy control subjects.

Table-III illustrates the level of circulatory lipid peroxidation and antioxidant status in control and diabetic subjects. The extent of lipid peroxidation was significantly increased in diabetic patients when compared to healthy controls.
Table-III

Circulatory lipid peroxide and antioxidant status in control and diabetic subjects

\begin{tabular}{lcr}
\hline Parameter & $\begin{array}{c}\text { Control } \\
\text { subjects }\end{array}$ & $\begin{array}{c}\text { Diabetic } \\
\text { patients }\end{array}$ \\
\hline TBARS (nmole/ml) & $2.96 \pm 0.21$ & $7.12 \pm 0.25^{* * *}$ \\
SOD (Unit $\left.{ }^{\mathrm{a}} \mathrm{mg} / \mathrm{Hb}\right)$ & $3.21 \pm 0.36$ & $2.54 \pm 0.17^{* * *}$ \\
CAT (Unit $\left.{ }^{\mathrm{b}} \mathrm{mg} / \mathrm{Hb}\right)$ & $67.5 \pm 7.60$ & $50.7 \pm 6.70^{* * *}$ \\
GPx (Unit $\left.{ }^{\mathrm{c}} \mathrm{mg} / \mathrm{Hb}\right)$ & $8.15 \pm 1.69$ & $6.53 \pm 0.85^{* * *}$ \\
GST (Unit $\left.{ }^{\mathrm{d}} \mathrm{mg} / \mathrm{Hb}\right)$ & $2.10 \pm 0.30$ & $1.12 \pm 0.35^{* * *}$ \\
GSH (mg/dl) & $36.18 \pm 1.67$ & $28.09 \pm 3.14^{* *}$ \\
Vitamin A (mg/dl) & $0.87 \pm 0.08$ & $0.54 \pm 0.061^{* * *}$ \\
Vitamin C (mg/dl) & $1.31 \pm 0.21$ & $0.74 \pm 0.13^{* * *}$ \\
Vitamin E (mg/dl) & $1.32 \pm 0.28$ & $0.53 \pm 0.13^{* * *}$ \\
\hline
\end{tabular}

Values are given as mean \pm S.D from 50 subjects in each group.

Diabetic patients compared with control subjects $(* * \mathrm{p}<0.01, * * * \mathrm{p}<0.001)$

a- One unit of activity was taken as the enzyme reaction, which gave $50 \%$ inhibition of NBT reduction in one minute. $\mathrm{b}$ - $\mu$ mole of $\mathrm{H}_{2} \mathrm{O}_{2}$ consumed/minute.

c - $\mu \mathrm{g}$ of GSH consumed $/ \mathrm{min}$.

$\mathrm{d}$ - $\mu$ mole of CDNB-GSH conjugate formed $/ \mathrm{min}$.

For studying the deleterious consequence of diabetes on antioxidant status, the activities of enzymatic antioxidants SOD, CAT, GPx, GST and nonenzymatic antioxidants GSH, vitamin A, vitamin C, vitamin $\mathrm{E}$ were measured. The activities of enzymatic and the levels of non-enzymatic antioxidant were significantly decreased in diabetic patients when compared to healthy control subjects.

Table-IV illustrates the levels of serum thyroid hormone status in diabetic and non-diabetic subjects.

\section{Table-IV}

Serum thyroid hormone status in diabetic and non-diabetic subjects

\begin{tabular}{lcc}
\hline Parameter & $\begin{array}{c}\text { Control } \\
\text { subjects }\end{array}$ & $\begin{array}{c}\text { Diabetic } \\
\text { patients }\end{array}$ \\
\hline TSH $(\mathrm{mIU} / \mathrm{ml})$ & $2.35 \pm 1.25$ & $1.92 \pm 1.03^{*}$ \\
T4 $(\mu \mathrm{g} / \mathrm{dl})$ & $8.51 \pm 2.20$ & $10.86 \pm 4.83^{* *}$ \\
T3 $(\mathrm{ng} / \mathrm{ml})$ & $0.91 \pm 0.37$ & $1.02 \pm 0.65^{\mathrm{NS}}$ \\
FT4 $(\mathrm{ng} / \mathrm{ml})$ & $1.35 \pm 0.74$ & $1.73 \pm 0.83^{*}$ \\
FT3 $(\mathrm{pg} / \mathrm{ml})$ & $2.80 \pm 0.83$ & $3.09 \pm 0.77^{\mathrm{NS}}$ \\
\hline
\end{tabular}

Values are given as mean \pm S.D from 50 subjects in each group. Diabetic patients compared with non-diabetic subjects (* $\mathrm{p}<0.05,{ }^{* *} \mathrm{p}<0.01$, NS - Not significant) 
The level of TSH was significantly decreased whereas the levels of $\mathrm{T}_{4}$ and $\mathrm{FT}_{4}$ were significantly increased in diabetic patients compared to control subjects. However, the levels of $\mathrm{T}_{3}$ and $\mathrm{FT}_{3}$ in diabetic and non-diabetic subjects did not differ significantly.

\section{Discussion}

Diabetes mellitus is a complex and multifactorial disease. The metabolic dysregulation associated with diabetes causes secondary pathophysiologic changes in multiple organ systems that impose a heavy burden of morbidity and mortality from macrovascular and microvascular complications ${ }^{26}$.

$\mathrm{HbA}_{1 \mathrm{C}}$ was found to increase in patients with diabetes to approximately $16 \%$ and the amount of increase is directly proportional to the fasting blood glucose level. During diabetes the excess glucose present in blood reacts with hemoglobin 27,28 . In the present study, we noticed a marked increase in $\mathrm{HbAl}_{\mathrm{C}}$ level in diabetic patients, which could be due to excessive glycosylation of hemoglobin. Increased blood urea production in diabetes may be accounted for by enhanced catabolism of both liver and plasma proteins ${ }^{29}$.

Diabetes has been shown to be associated with numerous thrombotic, atherosclerotic, and cardiovascular diseases. Cholesterol has been singled out as the cause of atherosclerosis. However, other lipids, such as triglycerides and phospholipids, also show similar correlations ${ }^{30}$. In our study, the levels of serum lipids were found to be elevated in diabetic patients. The abnormally high concentration of serum lipids in diabetes is mainly a result of the increase in mobilization of free fatty acids from peripheral depots, because insulin inhibits the hormone-sensitive lipase. On the other hand, glucagons, catecholamines, and other hormones enhance lipolysis The levels of VLDL$\mathrm{C}, \mathrm{LDL}-\mathrm{C}$, and HDL-C increase or decrease with the level of total serum cholesterol, and it is their ratio that determines the pathophysiology of lipoprotein metabolism ${ }^{30,31}$.

Lipid peroxide-mediated damage has been observed in the development of type 1 and type 2 diabetes mellitus. Insulin secretion is also closely associated with lipoxygenase-derived peroxides ${ }^{32}$. Low levels of lipoxygenase peroxides stimulate the secretion of insulin, but when the concentration of endogenous peroxides increases, it may initiate uncontrolled lipid peroxidation leading to cellular infiltration and islet cell damage.
Antioxidants constitute the foremost defense system that limit the toxicity associated with free radicals. The levels of these defense mechanisms are altered in diabetes. ${ }^{33}$ SOD and CAT are considered primary enzymes since they are involved in the direct elimination of ROS. The observed decrease in SOD and CAT activity could result from inactivation by $\mathrm{H}_{2} \mathrm{O}_{2}$ or by glycation of the enzyme, which have been reported to occur in diabetes ${ }^{34}$.

We have observed a significant decrease in GSH content in diabetic erythrocytes. The decrease in GSH content represents increased utilization due to oxidative stress. The depletion of GSH level may also lower the GST activity, as GSH is required as a substrate for GST activity ${ }^{35}$. Depression in GPx activity was also observed in erythrocytes during diabetes. GPx has been shown to be an important adaptive response to condition of increased peroxidative stress.

Earlier research has shown that diabetics have low levels of vitamin- $\mathrm{C}$ and vitamin $\mathrm{E}$ and that vitamin- $\mathrm{E}$ supplementation can help prevent the development of glucose intolerance and diabetes ${ }^{36}$. The present study showed that people with diabetes had lower level of âcarotene than people without diabetes. Recent studies have also shown that plasma concentrations of vitamin A and its carrier proteins, retinol-binding protein, and transthyretin are decreased in diabetic patients ${ }^{37}$. The underlying cause for decreased availability of this vitamin in diabetes is not clearly understood. It appears that the increased hepatic store of vitamin $A$ is attributed to a decreased availability of its carrier proteins.

The thyroid hormones, triiodothyronine and tetraiodothynine are insulin antagonists that also potentiate the action insulin indirectly ${ }^{38}$. TRH synthesis decreases in diabetes and these facts could be responsible for the occurrences of low thyroid hormone levels in diabetics. In our study, the TSH was significantly lower in diabetics than in nondiabetics. The abnormal thyroid hormones levels may be the outcome of the various medications the diabetics were receiving. For example, it is known that insulin; an anabolic hormone enhances the levels of $\mathrm{FT}_{4}$ while it suppresses the levels of $\mathrm{T}_{3}$ by inhibiting hepatic conversion of $\mathrm{T}_{4}$ to $\mathrm{T}_{3}$. On the other hand, some of the oral hypoglycemic agents such as the phenylthioureas are known to suppress the levels of $\mathrm{FT}_{4}$ and $\mathrm{T}_{4}$, while causing raised levels of $\mathrm{TSH}^{39}$. 
These situations may explain the finding of low or raised thyroid hormone status in diabetic subjects. Never the less the situation in these diabetics does not seem to follow the pattern previously recorded in other non-thyroidal diseases such as liver diseases and Cushing syndrome where low thyroid hormone levels were recorded. The presence of both raised and low levels of thyroid hormones levels in diabetics in this study may also be due to modified TRH synthesis and release and may depend on the glycemic status of the diabetics studied. Glycemic status is influenced by insulin, which is known to modulate TRH and TSH levels ${ }^{40}$.

The TSH level in diabetic males was significantly lower than the level in females. The incidence of hyperthyroidism was lower in females than in males, but the number of subjects in hypothyroid state was higher in females than in males. This finding is probably associated with the higher prevalence of obesity recorded in female diabetics. Insulin, which is used in treating diabetes and is produced in normal quantities or in excess, has been associated with increased anabolic activity ${ }^{41}$.

Suzuki et al. ${ }^{39}$ attributed the abnormal thyroid hormone levels found in diabetes to the presence of thyroid hormone binding inhibitor (THBI), an inhibitor of extra thyroidal conversion enzyme of $\mathrm{T}_{4}$ to $\mathrm{T}_{3}$, and dysfunction of the hypothalamo-pituitary-thyroid axis. These situations may prevail in diabetics and would be aggravated in poorly controlled diabetics. Stress, which is associated with diabetes, may also cause changes in the hypothalamus anterior-pituitary axis in these diabetics. It appears that the presence of subclinical hypothyroidism and hyperthyroidism may result from hypothalamus-hypophyseal-thyroid-axis disorders as suggested by Celani et al. ${ }^{42}$. Failure to recognize the presence of these abnormal thyroid hormone levels in diabetics may be a primary cause of poor management often encountered in some treated diabetics. There is therefore need for routine assay of thyroid hormone on diabetics, particularly those whose conditions are difficult to manage.

In conclusion, our findings demonstrate that detection of thyroid hormone status in addition to other biochemical variables in the early stage of the disease will help the patient to improve and reduce the morbidity rate.

\section{References}

1. Wild S, Roglic G, Green A, Sicree R, King H. Global prevalence of diabetes: estimates for the year 2000 and projections for 2030. Diabetes Care 2004; 27: 1047-1053.
2. Tiwari AK, Madhusudana Rao J. Diabetes mellitus and multiple therapeutic approaches of phytochemicals: Present status and future prospects. Current Science 2002; 83: 30-38.

3. Sheetz MJ, King GL. Molecular understanding of hyperglycemia's adverse effects for diabetic complications. JAMA 2002; 288: 2579-2588.

4. Preet A, Gupta BL, Yadava PK, Baquer NZ. Efficacy of lower doses of vanadium in restoring altered glucose metabolism and antioxidant status in diabetic rat lenses. Journal of Biosciences 2005; 30: 221-230.

5. Halliwell B, Whiteman M. Measuring reactive species and oxidative damage in vivo and in cell culture: how should you do it and what do the results mean?. British Journal of Pharmacology 2004; 142: 231-255.

6. Halliwell B. Role of free radicals in the neurodegenerative diseases: therapeutic implications for antioxidant treatment. Drugs \& Aging 2001; 18: 685-716.

7. Donne ID, Ranieri R, Roberto C, Daniela G, Aldo M. Biomarkers of oxidative damage in human disease. Clinical Chemistry 2006; 52: 601-623.

8. Donald DH. Oxidative stress and vascular disease. Arteriosclerosis, Thrombosis, and Vascular Biology 2005; 26: 689-695.

9. Mahboob M, Rahman MF, Grover P. Serum lipid peroxidation and antioxidant enzyme levels in male and female diabetic patients. SMJS 2005; 46:322-324.

10. Xi LS, Fan HF, Jian GZ, et al., Advanced oxidation protein products accelerate atherosclerosis through promoting oxidative stress and inflammation. Arteriosclerosis Thrombosis and Vascular Biology 2006; 26: 1156-1162.

11. Perros P, McCrimmon R, Shaw G, Frier B. Frequency of thyroid dysfunction in diabetic patients: value of annual screening. Diabet. Med 1995; 7: 622-627.

12. Calvo R, Escobar MG, Escobar Rey F, Oberegon MJ. Maternal nonthyroidal illness and fetal thyroid hormone status, as studied in the streptozotocininduced diabetes mellitus rat model. Endocrinology 1997; 138:1159-1169.

13. Udiong CEJA, Udoh E, Etukudoh ME. Evaluation of thyroid function in diabetes mellitus in calabar, Nigeria. Indian Journal of Clinical Biochemistry 2007; 22: 74-78.

14. Firoozrai M, Nourbakhsh M, Razzaghy-Azar M. Erythrocyte susceptibility to oxidative stress and antioxidant status in patients with type 1 diabetes. Diabetes Research and Clinical Practice 2007; 77: 427-432.

15. Friedewald WT, Levy RI, Fredrickson DS. Estimation of the concentration of low-density 
lipoprotein cholesterol in plasma, without use of the preparative ultracentrifuge. Clinical Chemistry 1972; 18: 499-502.

16. Yagi K. Lipid peroxides and human diseases. Chem Phys Lipids 1978; 45: 337-351.

17. Kakkar PS, Das B, Viswanathan PN. A modified spectrophotometric assay of superoxide dismutase. Indian J Biochem Biophys 1984; 21:130-132.

18. Sinha, KA. Colorimetric assay of catalase. Anal Biochem. 1972; 47: 389-394.

19. Rotruck JT, Pope AL, Ganther HE, Swanson AB, Hafeman DG, and Hoekstra WG. Selenium: biochemical roles as a component of glutathione peroxidase. Science 1973; 179: 588-590.

20. Ellman GL. Tissue sulfhydryl groups. Arch Biochem Biophys 1959; 82:70-77.

21. Habig WH, Pabst MJ, Jakoby WB. Glutathione-Stransferases, the first enzymatic step in mercapturic acid formation. J Biol Chem 1974; 249: 7130-7139.

22. Lowry OH, Rosenbrough MJ, Farr AL, Randall RJ. Protein measurement with Folin-Phenol reagent. Journal of Biological Chemistry 1951; 193: 265-275.

23. Bradley DW, Hombeck CL. Clinical evaluation and improved TFA micro method for plasma and serum vitamin (A) b-carotein. Biochem Med 1973; 7: 78-86.

24. Baker H, Frank O, De Angelis B, Feingold S. Plasma tocopherol in man at various times after ingesting free or acetylated tocopherol. Nutrition Report International, 1980; 21: 531- 536.

25. Roe HJ, Kuether CA. Detection of ascorbic acid in whole blood and urine through the 2, 4dinitrophenyl-hydrazine derivative of dehydro ascorbic acid. Journal of Biological Chemistry, 1943; 147: 399- 407.

26. American Diabetes Association, Diagnosis and classification of diabetes mellitus. Diab Care 2005; 28: $37-42$.

27. Gloria-Botthini F, Antonacci E, Bottini N, et al. Rh blood groups and diabetic disorders: Is there an effect on glycosylated hemoglobin level. Hum Bio 2000; 72: 287-294.

28. Sampson MJ, Hughes DA, Carrier MJ, Davies IR. Status of HbA1c during acute hyperglycemia in type 2 diabetes. Diabetes care 2002; 25: 537-541.

29. Prakasam A, Sethupathy S, Pugalendi KV. Influence of Casearia esculenta root extract on protein metabolism and marker enzymes in streptozotocininduced diabetic rats. Pol J Pharmacol Pharm 2004; 56: 587-593.
30. Venkateswaran S, Pari L, Saravanan G. Effect of Phaseolus vulgaris on circulatory antioxidants and lipids in rats with streptozotocin-induced diabetes. Journal of Medicinal Food 2002; 5: 97-103.

31. Suryawanshi NP, Bhutey AK, Nagdeote AN, Jadhav AA, Manoorkar GS. Study of lipid peroxide and lipid profile in diabetes mellitus. Indian Journal of Clinical Biochemistry 2006; 21: 126-130.

32. Kuyvenhoven JP, Meinders AE. Oxidative stress and diabetes mellitus pathogenesis of long-term complications. EJIM 1999; 10: 9-19.

33. Ramachandran B, Ravi K, Narayanan V, Kandaswamy M, Subramanian S. Effect of macrocyclic binuclear oxovanadium complex on tissue defense system in streptozotocin-induced diabetic rats. Clinca Chimica Acta 2004; 345: 141150 .

34. Sozmen EY, Sozmen B, Delen Y, Onat T. Catalase/ superoxide dismutase (SOD) and catalase/ paraoxonase $(\mathrm{PON})$ ratios may implicate poor glycemic control. Archives of Medical Research 2001; 32: 283-287.

35. Rathore N, Kale M, John S, Bhatnagar D. Lipid peroxidation and antioxidant enzymes in isoproterenol induced oxidative stress in rat erythrocytes. Indian Journal of Physiology and Pharmacolog 2000; 44: 161-166.

36. Ford ES, Will JC, Bowman BA, Venkat Narayan KM. Diabetes mellitus and serum carotenoids: findings from the third national health and nutrition examination survey. Am J Epidemiol 1999; 149: 168-176.

37. Basu TK, Basualdo C. Vitamin A homeostasis and diabetes mellitus. Nutrition 1997; 13: 804-806

38. Johnson JL, Duick, DS. Diabetes and thyroid disease: A likely combination. Diabetes Spectrum $2002 ; 15: 140-142$.

39. Suzuki J, Nanno M, Gemma R, Tanaka I, Taminato $\mathrm{T}$, Yoshimi T. The mechanism of thyroid hormone abnormalities in patients with diabetes mellitus. Nippon Niabunpi Gakki Zasshi 1994; 7: 465-470.

40. Reusch CE, Tomsa K. Serum fructosamine concentration in cats with overt hyperthyroidism. J American Vet Med Asso 1999; 215: 1297-1330.

41. Khandekar S. Therapy related weight gain among non-insulin dependent diabetics in Saudi Arabia. Pract. Diabetes Digest 1991; 2: 84-86.

42. Celani MF, Bonati ME, Stucci N. Prevalence of abnormal thyrotropin concentrations measured by a sensitive assay in patients with type 2 diabetes mellitus. Diabetes Res 1994; 27: 15-25. 